\title{
OPTIMALISASI KEWENANGAN MAJELIS PENGAWAS WILAYAH NOTARIS PROVINSI MALUKU
}

\author{
Nasaruddin Umar ${ }^{1}$, Fahri Bachmid ${ }^{2 *}$ \\ ${ }^{1}$ Dosen Fakultas Syariah dan Ekonomi Islam, Institut Agama Islam Negeri Ambon \\ ${ }^{2}$ Dosen Fakultas Hukum, Universitas Muslim Indonesia, Makassar \\ *Penulis Korespondensi: Fahri Bachmid \\ Email Korespondensi:fahri.bachmid@umi.ac.id
}

\begin{abstract}
Abstrak. Penelitian ini bertujuan untuk mengetahui dan menganalisis optimalisasi kewenangan Majelis Pengawas Wilayah Notaris Provinsi Maluku Tahun 2017-2020, serta faktor-faktor yang mempengaruhinya. Tipe penelitian yang digunakan adalah penelitian hukum empiris yang bersifat deskriptif kualitatif. Penelitian ini dilakukan di Provinsi Maluku. Teknik pengumpulan data yang digunakan dalam penelitian ini adalah wawancara, dokumentasi, dan studi pustaka. Adapun teknik analisis data yang digunakan adalah teknik analisis data kualitatif. Hasil penelitian menunjukkan bahwa optimalisasi kewenangan Majelis Pengawas Wilayah Notaris Provinsi Maluku Tahun 2017-2020 telah berjalan sebagaimana berdasarkan Pasal 73 UU No. 2 Tahun 2014. Akan tetapi, terdapat beberapa faktor kendala dari sisi efektivitas fungsi kewenangan, khususnya faktor regulasi dan faktor penerapan sanksi. Selanjutnya, disarankan agar dilakukan revisi pada Pasal 73 UU No. 2 Tahun 2014, yaitu dengan memperkuat atau memperluas kewenangan Majelis Pengawas Wilayah melalui model Pencegahan dan Pengawasan Aktif, dimana dijalankan secara berkala maupun setiap waktu berdasarkan keperluan informasi terkait dugaan pelanggaran pelaksanaan jabatan Notaris dan pelanggaran perilaku Notaris.
\end{abstract}

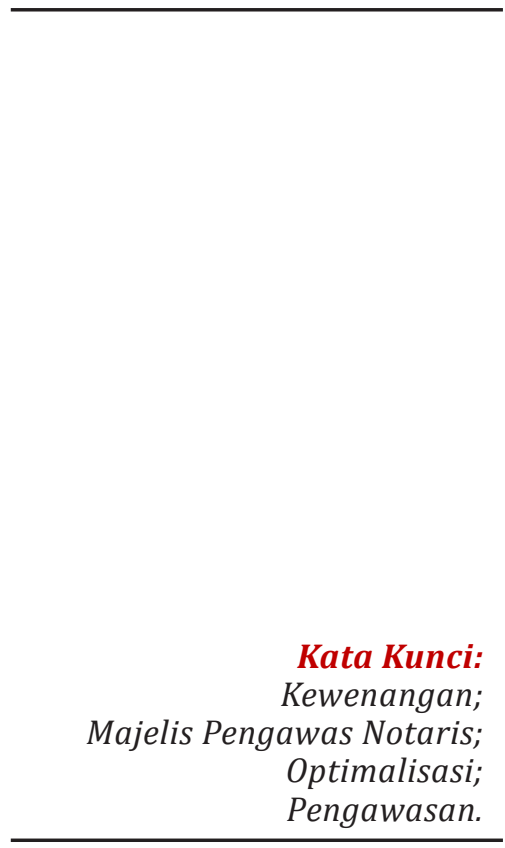

Artikel dengan akses terbuka di bawah lisensi CC BY SA-4.0

\section{PENDAHULUAN}

Profesi jabatan Notaris merupakan jabatan umum yang sangatpenting dalam kehidupan masyarakat, berbangsa, dan bernegara (Aris Yulia, 2019). Sebagaimana berdasarkan Konsideran Bagian Menimbang poin c Undang-Undang Republik Indonesia Nomor 2 Tahun 2014 tentang Perubahan atas Undang-Undang Nomor 30 Tahun 2004 tentang Jabatan Notaris (selanjutnya disebut UU No. 2 Tahun 2014), menjelaskan bahwa:

"Notaris merupakan jabatan tertentu yang menjalankan profesi dalam pelayanan hukum kepada masyarakat, perlu mendapatkan perlindungan dan jaminan demi tercapainya kepastian hukum"

Sementara itu, di tengah proses pembangunan di Maluku yang terus berkembang dan salah satu efek ialah terjadinya peningkatan kebutuhan jasa Notaris dalam melayani 
dan memberikan kepastian hukum terhadap setiap masyarakat yang membutuhkan akta autentik (Henny Saida Flora, 2012). Namun keberadaan pejabat Notaris yang tersebar di berbagai Kabupaten/Kota di Provinsi Maluku dinilai masih memiliki permasalahan, sehingga diperlukan solusi agar dapat menghindari hambatan dan mempercepat kebutuhan dan aktivitas masyarakat (Jeffry Tanugraha, 2013). Hal senada juga dikemukakan oleh M. J. Mataheru, bahwa: ${ }^{1}$

"Keberadaan 40 pejabat notaris di Maluku memiliki sejumlah permasalahan
seperti masalah keaktifan di daerah, kinerja dan profesionalisme pejabat
notaris di Maluku dalam melayani masyarakat, di samping faktor kondisi
Geografis Maluku yang berkarakter kepulauan yang menyebabkan
terjadinya berbagai kendala dalam hal pembinaan dan pengawasan baik
dari Kemenkumham sendiri maupun dari Majelis Pengawas Wilayah dan
Majelis Pengawas Daerah."

Hal tersebut di atas juga diperkuat dari adanya kasus dan laporan yang berkaitan dengan dugaan pelanggaran yang dilakukan oknum pejabat Notaris di Maluku, seperti laporan dari masyarakat tanggal 31 Januari 2018 atas dugaan bahwa oknum berinisial RW selaku pejabat Notaris juga rangkap jabatan sebagai Advokat dan masih aktif dan terdaftar sebagai anggota Peradi. Selain itu, terdapat pula oknum Notaris berinisial CL selaku narapidana kasus tindak pidana narkoba, namun diduga telah menandatangani sebuah akta saat berada di dalam penjara. Selanjutnya, berbagai kasus lain yang terjadi seperti ketidakjelasan kantor dan keberadaan oknum Notaris yang tidak bertugas tanpa izin dan kinerja serta tidak adanya laporan rutin sejumlah Notaris (Olivia Yanuari Huslan, 2019).

Pada sisi regulasi, UU No. 2 Tahun 2014 masih menyimpan berbagai kelemahan. Salah satu kelemahannya terdapat pada aspek kewenangan dari ketiga badan Majelis Pengawas, yakni Majelis Pengawas Daerah (MPD), Majelis Pengawas Wilayah (MPW), dan Majelis Pengawas Pusat (MPP) dimana hubungannya bersifat hirarkis, misalnya hubungan antara MPD dengan MPW dimana setiap laporan yang disampaikan MPD akan diperiksa, disidangkan, dan diputuskan oleh MPW (Neky Kuntjoro, 2016). Selanjutnya, kewenangan memberikan sanksi administrasi termasuk izin cuti tidak diberikan kepada MPD melainkan pada MPW, Majelis Pengawas Pusat dan Menteri Hukum dan HAM RI. Disinilah posisi MPW menjadi strategis dan menjadi ujung tombak dalam menjatuhkan sanksi terhadap notaris (Endang Purwaningsih, 2015).

Oleh karena itu, berdasarkan fakta dan ketentuan dalam UU No. 2 Tahun 2014, maka keberadaan dan efektifitas kinerja MPWN Provinsi Maluku akan sangat menentukan keberhasilan pengawasan Notaris di Maluku. Jika MPW dalam mengawasi tugas, kewenangan jabatan Notaris lebih efektif dan optimal, maka kualitas pelayanan hukum dan perlindungan kepada masyarakat akan meningkat (Eureika Kezia Sakudu \& Wahyuni Safitri, 2017). Akan tetapi, apabila pengawasan MPW tidak maksimal dalam memberikan sanksi kepada notaris yang bermasalah, maka berdampak pada terjadinya distrust atau ketidakpercayaan publik kepada Pemerintah dan Negara Indonesia sendiri (Sri Yuniati, 2017), sebab keberadaan Majelis Pengawas merupakan representasi Pemerintah dalam mengawasi Notaris di Maluku.

${ }^{1}$ Wawancara dengan Kepala Divisi Pelayanan Hukum dan HAM, serta anggota Majelis Pengawas Wilayah Notaris Provinsi Maluku, M. J. Mataheru, pada Bulan Juli dan September 2020. 
Berdasarkan uraian di atas, maka tujuan penelitian ini adalah untuk mengetahui dan menganalisis optimalisasi kewenangan MPWN Provinsi Maluku Tahun 2017-2020, serta faktor-faktor yang mempengaruhinya.

\section{METODE PENELITIAN}

Penelitian ini merupakan penelitian hukum empiris, yakni penelitian yang memandang hukum dalam konteks sosialnya (Said Sampara \& La Ode Husen, 2016), dan berkaitan dengan kewenangan Majelis Pengawas Notaris. Penelitian ini dilaksanakan di Provinsi Maluku. Jenis data yang digunakan dalam penelitian ini, adalah sebagai berikut:

1. Data Primer, adalah data yang bersumber dari hasil penelitian lapangan, yakni dari beberapa informan yang telah ditetapkan sebagai sample penelitian.

2. Data Sekunder, adalah data yang bersumber dari penelusuran bahan hukum kepustakaan, berupa dokumen resmi dari instansi terkait, peraturan perundangundangan, jurnal ilmiah hukum, ensiklopedia hukum, maupun dari teks atau terbitan resmi.

Untuk memperoleh data yang dibutuhkan dalam penelitian ini, maka digunakan teknik pengumpulan data, yakni sebagai berikut:

1. Wawancara, yakni dilakukan dengan cara interview secara langsung dengan pihakpihak yang dipandang kompeten memberikan informasi langsung berkenaan dengan masalah yang dikaji dalam penelitian ini;

2. Dokumentasi, dilakukan dengan cara permintaan secara resmi tentang dokumen terkait;

3. Studi Kepustakaan, dilakukan dengan cara menginventarisasi dan menganalisis bahan-bahan hukum kepustakaan yang berkenaan dengan masalah yang dikaji dalam penelitian.

Data yang telah terkumpul, kemudian dibahas dan dianalisis dengan menggunakan model analisis deskriptif, dengan menguraikannya dalam bentuk naratif. Data primer dan data sekunder yang berhasil dihimpun selama berlangsungnya penelitian, kemudian disusun secara sistematik serta dianalisis secara kualitatif menurut validitas dan reliabilitasnya (Nasaruddin Umar \& Fahri Bachmid, 2020).

\section{HASIL DAN PEMBAHASAN}

\section{A. Substansi Pengawasan dan Pembinaan Notaris}

Pengawasan menurut Lord Acton dalam Diana Halim Koentjoro (2004), diuraikan bahwa:

"Tindakan yang bertujuan untuk mengendalikan sebuah kekuasaan yang dipegang oleh Pejabat Administrasi Negara (Pemerintah) yang cenderung disalahgunakan, tujuannya untuk membatasi Pejabat Administrasi Negara agar tidak menggunakan kekuasaan di luar batas kewajaranyang bertentangan dengan ciri Negara Hukum, untuk melindungi masyarakat dari tindakan diskresi Pejabat Administrasi Negara dan melindungi Pejabat Administrasi Negara agar menjalankan kekuasaan dengan baik dan benar menurut hukum atau tidak melanggar hukum." 
Selanjutnya, berdasarkan Pasal 1 angka 8 Keputusan Menteri Kehakiman dan Hak Asasi Manusia Republik Indonesia Nomor M-01.HT.03.01 Tahun 2003 tentang Kenotarisan, menjelaskan bahwa:

"Pengawasan adalah kegiatan administratif yang bersifat preventif dan represif oleh Menteri yang bertujuan untuk menjaga agar para Notaris dalam menjalankan jabatannya sesuai dengan peraturan perundangundangan."

Lebih lanjut, berdasarkan Pasal 1 angka 4 Peraturan Menteri Hukum dan Hak Asasi Manusia Republik Indonesia Nomor 40 Tahun 2015 tentang Susunan Organisasi, Tata Cara Pengangkatan Anggota, Pemberhentian Anggota, dan Tata Kerja Majelis Pengawas (selanjutnya disebut Permenkumham No. 40 Tahun 2015), menjelaskan bahwa:

"Pengawasan adalah kegiatan yang bersifat preventif dan kuratif termasuk kegiatan pembinaan yang dilakukan oleh Majelis Pengawas terhadap Notaris."

Adapun dalam perspektif kelembagaan formil, berdasarkan Pasal 1 angka 6 UU No. 2 Tahun 2014 jo. Pasal 1 angka 2 Permenkumham No. 40 Tahun 2015, menjelaskan bahwa:

"Majelis Pengawas Notaris yang selanjutnya disebut Majelis Pengawas adalah suatu badan yang mempunyai kewenangan dan kewajiban untuk melaksanakan pembinaan dan pengawasan terhadap Notaris."

Dari ketentuan di atas, kata pembinaan yang diletakkan di depan dimaksudkan agar mempunyai fungsi sebagai lembaga pengawasan (Abdul Bari Azed, 2008). Dilain sisi, para legislator sebagai pembentuk UU No. 2 Tahun 2014 memiliki tujuan tersendiri sehingga mendahulukan fungsi pembinaan dari pada fungsi pengawasan. Lebih lanjut, dimana Notaris sebagai jabatan atau profesi yang mulia (officium nobile), dengan mengedepankan fungsi pembinaan maka diharapkan seorang Notaris harus mampu menjaga kehormatan, martabat dan tanggung jawab sebagai jabatan yang mulia tersebut. Adapun deskripsi dari kedua fungsi tersebut yang oleh Erna Ristiani (2010) menguraikan bahwa:

"Fungsi pembinaan ditujukan agar yang diawasi, yaitu Notaris selalu diingatkan untuk memahami dan mematuhi aturan-aturan baik yang berupa kode etik Notaris maupun ketentuan-ketentuan dalam peraturan perundang-undangan yang berlaku. Sedangkan fungsi pengawasan kepada Notaris ditujukan agar dalam menjalankan jabatannya Notaris senantiasa mematuhi ketentuan peraturan perundang-undangan yang berlaku, karena apabila seorang Notaris terbukti melakukan pelanggaran maka akan dikenakan sanksi. Sanksi tersebut dapat berupa teguran lisan, teguran tertulis, pemberhentian sementara, sampai dengan pemberhentian dengan tidak hormat."

Adapun aspek kewenangan Notaris dalam mengawasi perilaku dan kinerja Notaris, sebagaimana berdasarkan Pasal 67 UU No. 2 Tahun 2014, mengatur bahwa:

(1) Pengawasan atas Notaris dilakukan oleh Menteri.

(2) Dalam melaksanakan pengawasan sebagaimana dimaksud pada ayat (1) Menteri membentuk Majelis Pengawas.

(3) Majelis Pengawas sebagaimana dimaksud pada ayat (2) berjumlah 9 (sembilan) orang, terdiri atas unsur: 
a. Pemerintah sebanyak 3 (tiga) orang;

b. Organisasi Notaris sebanyak 3 (tiga) orang; dan

c. ahli atau akademisi sebanyak 3 (tiga) orang.

(4) Dalam hal suatu daerah tidak terdapat unsur instansi pemerintah sebagaimana dimaksud pada ayat (3) huruf a, keanggotaan dalam Majelis Pengawas diisi dari unsur lain yang ditunjuk oleh Menteri.

(5) Pengawasan sebagaimana dimaksud pada ayat (1) meliputi perilaku Notaris dan pelaksanaan jabatan Notaris.

(6) Ketentuan mengenai pengawasan sebagaimana dimaksud pada ayat (5) berlaku bagi Notaris Pengganti dan Pejabat Sementara Notaris.

Selanjutnya, berdasarkan Pasal 68 UU No. 2 Tahun 2014, mengatur bahwa Majelis Pengawas ... terdiri atas:

a. Majelis Pengawas Daerah;

b. Majelis Pengawas Wilayah; dan

c. Majelis Pengawas Pusat.

\section{B. Konsep Kewenangan menurut Ahli Hukum}

Kewenangan menurut Kamus Besar Bahasa Indonesia (KBBI) adalah "kekuasaan membuat keputusan memerintah dan melimpahkan tanggung jawab kepada orang lain". Adapun menurut Aminuddin Ilmar (2018) bahwa:

"Wewenang khususnya wewenang pemerintahan merupakan suatu kekuasaan yang ada pada pemerintahan untuk menjalankan fungsi dan tugasnya berdasar peraturan perundang-undangan."

Kedudukan wewenang merupakan hal yang begitu penting, karena bertalian dengan kekuasaan dan pelimpahan tanggungjawab, maka dibutuhkan kompetensi bagi pengemban kewenangan, sebagaimana yang telah diungkapkan oleh F. A. M. Stroink \& J. G. Steenbeek (1985), bahwa:

"HET begrip bevoegdheid is dan ook een kembergrip in het staats-en administratief recht (Wewenang merupakan konsep inti dari Hukum Administrasi Negara dan Hukum Tata Negara)."

Selanjutnya, Philipus M. Hadjon et al. (2011) berdasarkan kepustakaan hukum administrasi Belanda, mengemukakan bahwa:

"Kewenangan atau wewenang selalu menjadi bagian penting dan bagian awal dari hukum administrasi, karena objek hukum administrasi adalah wewenang pemerintahan dalam konsep hukum publik."

Philipus M. Hadjon et al. (2011) mengidentifikasi wewenang sebagai konsep publik, dimana sekurang-kurangnya terdiri dari 3 (tiga) komponen (Abdul Latif, 2014), yaitu:

1. Pengaruh, dimana untuk mengendalikan perilaku subjek hukum agar pejabat negara tidak menggunakan wewenangnya di luar dari tujuan yang ditentukan oleh peraturan perundang-undangan.

2. Dasar Hukum, dimana untuk memastikan bahwa setiap pejabat negara harus selalu mempunyai dasar hukum dalam hal bertindak. 
3. Konformitas Hukum, dimana untuk memberikan standarisasi kewenangan, baik standar umum (semua jenis wewenang) maupun standar khusus (untuk jenis wewenang tertentu).

Tatiek Sri Djatmiati (2004) lebih lanjut menguraikan keterkaitan hubungan antara Hukum dengan kewenangan, bahwa:

"Hukum Administrasi Negara (administratiefrecht) atau Hukum Tata Negara (bestuursrecht) berisikan norma-norma hukum pemerintahan dan menjadi parameter dalam penggunaan kewenangan oleh badanbadan pemerintah."

Dengan kata lain, wewenang merupakan kekuasaan yang mempunyai landasan untuk mengambil tindakan atau perbuatan hukum yang tidak timbul akibat hukum, yakni terwujudnya kesewenang-wenangan (onwetmatig). Wewenang adalah kekuasaan hukum untuk menjalankan atau melakukan suatu tindakan atau perbuatan berdasarkan hukum publik. Dalam konsep hukum perdata, hal tersebut dikenal dengan istilah hak, yakni kemampuan seseorang untuk melakukan suatu tindakan atau perbuatan hukum sebagai pendukung hak dan kewajiban (Aminuddin Ilmar, 2018).

H. D. van Wijk (1976) kemudian menguraikan bahwa kewenangan atau wewenang dapat diperoleh melalui beberapa cara, yaitu:

1. Atribusi, dimana merupakan suatu pemberian wewenang pemerintahan oleh pembuat undang-undang kepada organ pemerintahan (attribute is toekenning van een bestuursbevoegheid door een wetgever aan een bestuursorgaan);

2. Delegasi, dimana merupakan suatu pelimpahan wewenang pemerintahan dari suatu organ pemerintahan kepada organ pemerintahan lainnya (delegatie is overdracht van een bevoegheid van het ene bestuursorgaan aan een ander); serta

3. Mandat, dimana ketika organ pemerintahan mengizinkan kewenangannya dijalankan oleh organ lain atas namanya (mandaat is een bestuursorgaan loot zijn bevoegheid namens hem uitoefenen door een ander).

Dari uraian di atas, sebagaimana berdasarkan Pasal 11 Undang-Undang Republik Indonesia Nomor 30 Tahun 2014 tentang Administrasi Pemerintahan (selanjutnya disebut UU No. 30 Tahun 2014), mengatur bahwa "kewenangan diperoleh melalui Atribusi, Delegasi, dan/atau Mandat".

Berdasarkan Pasal 1 angka 22 UU No. 30 Tahun 2014, menjelaskan bahwa:

"Atribusi adalah pemberian Kewenangan kepada Badan dan/atau Pejabat Pemerintahan oleh Undang-Undang Dasar Negara Republik Indonesia Tahun 1945 atau Undang-Undang."

Berdasarkan Pasal 1 angka 23 UU No. 30 Tahun 2014, menjelaskan bahwa:

"Delegasi adalah pelimpahan Kewenangan dari Badan dan/atau Pejabat Pemerintahan yang lebih tinggi kepada Badan dan/atau Pejabat Pemerintahan yang lebih rendah dengan tanggung jawab dan tanggung gugat beralih sepenuhnya kepada penerima delegasi." 
Berdasarkan Pasal 1 angka 24 UU No. 30 Tahun 2014, menjelaskan bahwa:

"Mandat adalah pelimpahan Kewenangan dari Badan dan/atau Pejabat Pemerintahan yang lebih tinggi kepada Badan dan/atau Pejabat Pemerintahan yang lebih rendah dengan tanggung jawab dan tanggung gugat tetap berada pada pemberi mandat."

Berkaitan dengan konsep cara memperoleh kewenangan dan yang diatur dalam UU No. 30 Tahun 2014, maka dalam konteks pelaksanaan kewenangan Pengawasan terhadap Notaris dapat dikatakan bahwa Menteri Hukum dan HAM memperoleh wewenang berdasarkan atribusi karena diamanatkan langsung oleh UU No. 2 Tahun 2014. Adapun pelaksanaan pembinaan dan pengawasan Notaris yang dilaksanakan oleh Majelis Pengawas dapat dipahami sebagai wewenang yang diperoleh berdasarkan mandat meskipun keanggotaan MPW tidak semuanya adalah bawahan Menteri.

\section{Pelaksanaan Fungsi Pengawasan MPWN Provinsi Maluku Tahun 2017-2020}

Sejak tahun 2017, MPWN Provinsi Maluku telah melakukan fungsi pengawasan terhadap para notaris yang ada di Maluku. Berdasarkan hasil penelusuran kajian dokumen-dokumen dalam proses pemeriksaan atas dugaan pelanggaran ketentuan peraturan perundang-undangan yang dilaporkan masyarakat, dari hasil kajian sejumlah dokumen seperti berita acara pemeriksaan, keputusan majelis pemeriksa, maka data dapat dilihat pada tabel di bawah ini.

Tabel 1. Putusan MPWN Provinsi Maluku Tahun 2017-2020

\begin{tabular}{c|c|c|c|c}
\hline \hline $\begin{array}{c}\text { Inisial } \\
\text { Notaris }\end{array}$ & Tanggal Putusan & $\begin{array}{c}\text { Pelanggaran UU No. 2 } \\
\text { Tahun 2014 }\end{array}$ & Jenis Putusan & Evaluasi \\
\hline \hline CL & 19 Agustus 2019 & Pasal 9 ayat (1) huruf e & $\begin{array}{c}\text { Rekomendasi } \\
\text { Pemberhentian Sementara }\end{array}$ & Sesuai \\
\hline RW & 31 Januari 2019 & Pasal 17 ayat (1) & Peringatan Tertulis & Sesuai \\
\hline MS & 11 Februari 2020 & Pasal 16 ayat (1) & Peringatan Tertulis & Sesuai \\
\hline MS & 11 Februari 2020 & $\begin{array}{c}\text { Pasal 16 ayat (1) huruf a } \\
\text { Pasal 17 ayat (1) huruf b }\end{array}$ & Peringatan Tertulis & Sesuai \\
\hline FG & 21 September 2020 & $\begin{array}{c}\text { Pasal 7 ayat (1) } \\
\text { Pasal 17 ayat (1) }\end{array}$ & Peringatan Tertulis & Sesuai \\
\hline GG & 21 September 2020 & $\begin{array}{c}\text { Pasal 7 ayat (1) } \\
\text { Pasal 16 ayat (1) huruf a } \\
\text { Pasat (1) }\end{array}$ & Peringatan Tertulis & Sesuai \\
\hline \hline
\end{tabular}

Sumber: Diolah dari Data MPWN Provinsi Maluku, Tahun 2020

Berdasarkan hasil matriks Pasal dalam UU No. 2 Tahun 2014, pelanggaran dengan jenis putusan yang dijatuhkan telah sesuai dengan ketentuan Peraturan Perundang-Undangan seperti UU No. 2 Tahun 2014 dan Peraturan Menteri Hukum dan Hak Asasi Manusia Republik Indonesia Nomor 61 Tahun 2016 tentang Tata Cara Penjatuhan Sanksi Administratif terhadap Notaris.

Sejak tahun 2017 hingga tahun 2020, MPWN Provinsi Maluku juga menemukan bahwa pelaksanaan tugas pengawasan masih sebatas jabatan Notaris saja, sedangkan bagi Notaris Pengganti dan Pejabat Sementara Notaris belum dilakukan. Hal ini disebabkan karena di Maluku, baik Notaris Pengganti dan Pejabat Sementara 
Notaris memang kurang. Selain itu, belum ada laporan atau pengaduan masyarakat kepada MPDN Kabupaten/Kota, sebagaimana berdasarkan Pasal 70 huruf g UU No. 2 Tahun 2014, yang mengatur bahwa:

"Majelis Pengawas Daerah berwenang menerima laporan dari masyarakat mengenai adanya dugaan pelanggaran Kode Etik Notaris atau pelanggaran ketentuan dalam Undang-Undang ini."

Adapun pelanggaran kode etik notaris berpedoman pada Kongres Luar Biasa Ikatan Notaris Indonesia Tahun 2015 tentang Perubahan Kode Etik Notaris. Selanjutnya, berdasarkan Pasal 70 huruf a UU No. 2 Tahun 2014, mengatur bahwa:

"Majelis Pengawas Daerah berwenang menyelenggarakan sidang untuk memeriksa adanya dugaan pelanggaran Kode Etik Notaris atau pelanggaran pelaksanaan jabatan Notaris."

Lebih lanjut, berdasarkan Pasal 70 huruf h UU No. 2 Tahun 2014, mengatur bahwa "Majelis Pengawas Daerah berwenang membuat dan menyampaikan laporan ... kepada Majelis Pengawas Wilayah". Dari hasil laporan oleh MPD kepada MPW, berdasarkan Pasal 73 ayat (1) huruf e UU No. 2 Tahun 2014, mengatur bahwa "Majelis Pengawas Wilayah berwenang memberikan sanksi berupa teguran lisan atau tertulis". Setelah MPW memberikan sebuah sanksi kepada Notaris yang telah melakukan pelanggaran, maka berdasarkan Pasal 73 ayat (2) UU No. 2 Tahun 2014, yang mengatur bahwa "Keputusan Majelis Pengawas Wilayah ... bersifat final".

Dari uraian di atas, secara umum dapat dinilai bahwa pada tahun 2017-2020, MPWN Provinsi Maluku telah melaksanakan kewenangannya. Akan tetapi dalam pelaksanaannya masih terdapat hambatan dan kekurangan dari sisi kepatuhan pejabat Notaris untuk melaksanakan keputusan MPWN Notaris Provinsi Maluku.

\section{Faktor-Faktor Penghambat Kewenangan MPWN Provinsi Maluku}

Berdasarkan hasil observasi, wawancara dan penelusuran dokumen hukum yang berkaitan pengawasan notaris oleh MPWN Provinsi Maluku, maka ditemukan beberapa kelemahan yang menghambat pengawasan notaris.

\section{Faktor Regulasi}

Faktor regulasi merupakan variabel yang menentukan dalam mengukur efektif atau tidaknya suatu penerapan kaidah hukum, sebagaimana yang dikemukakan oleh Hans Kelsen (1992), bahwa:

"Suatu aturan hukum harus dalam keadaan valid terlebih dahulu baru diketahui apakah aturan tersebut dapat menjadi efektif. Jika setelah diterapkan ternyata peraturan yang sebenarnya sudah valid namun ternyata tidak dapat diterapkan atau tidak dapat diterima oleh masyarakat secara meluas dan/atau secara terus menerus, maka ketentuan hukum tersebut menjadi hilang unsur validitasnya, sehingga berubah sifat dari aturan yang valid menjadi aturan yang tidak valid.

Pada sisi regulasi, berdasarkan Pasal 73 ayat (1) UU No. 2 Tahun 2014, mengatur bahwa Majelis Pengawas Wilayah berwenang:

a. menyelenggarakan sidang untuk memeriksa dan mengambil keputusan atas laporan masyarakat yang disampaikan melalui Majelis Pengawas Wilayah; 
b. memanggil Notaris terlapor untuk dilakukan pemeriksaan atas laporan ...;

c. memberikan izin cuti lebih dari 6 (enam) bulan sampai 1 (satu) tahun;

d. memeriksa dan memutus atas keputusan Majelis Pengawas Daerah yang menolak cuti yang diajukan oleh Notaris pelapor;

e. memberikan sanksi berupa teguran lisan atau tertulis;

f. mengusulkan pemberian sanksi terhadap Notaris kepada Majelis Pengawas Pusat berupa:

1) pemberhentian sementara 3 (tiga) bulan sampai dengan 6 (enam) bulan; atau

2) pemberhentian dengan tidak hormat.

g. membuat berita acara atas setiap keputusan penjatuhan sanksi ... .

Dari ketentuan di atas, dapat dinilai bahwa kewenangan MPWN Provinsi Maluku masih sangat terbatas dan bersifat pasif, dalam artian menunggu laporan dan penyampaian BAP dari MPDN Kabupaten/Kota. Dari semua kasus atau perkara yang ditangani MPWN Provinsi Maluku dari tahun 2017-2020, hampir semuanya berstatus tindak lanjut. Adapun laporan masyarakat ke MPDN Kabupaten/Kota, sisanya berupa monitoring atau kunjungan di lapangan.

\section{Faktor Penerapan Sanksi}

Faktor penerapan sanksi juga menjadi hambatan efektivitas pelaksanaan wewenang MPWN Provinsi Maluku, dari kurung waktu tahun 2017-2020. Apabila diperhatikan dan ditelaah lebih jauh, terdapat 5 (lima) putusan dimana dapat dilihat pada tabel di bawah ini.

Tabel 2. Jenis dan Jumlah Putusan MPWN Provinsi Maluku Tahun 2017-2020

\begin{tabular}{c|c|c}
\hline \hline Jenis Putusan & Jumlah Putusan & Implementasi Putusan \\
\hline \hline Pemberhentian & 1 Kasus & 1 Kasus \\
\hline Peringatan Tertulis & 4 Kasus & 1 Kasus \\
\hline \hline
\end{tabular}

Sumber: Diolah dari Data MPWN Provinsi Maluku, Tahun 2020

Berdasarkan hasil observasi di lapangan, penerapan sanksi MPWN Provinsi Maluku telah dilayangkan kepada yang bersangkutan, pelaksanaan putusan notaris yang telah diberi sanksi tidak sepenuhnya menaati. Dari 4 (empat) putusan sanksi peringatan tertulis, baru 1 (satu) melaksanakan rekomendasi dari MPWN sedangkan 3 (tiga) lainnya belum melaporkan hasil tindak lanjut dari rekomendasi yang diberikan. Adapun putusan usulan pemberhentian berdasarkan penyampaian Ketua MPDN Kabupaten/Kota dalam rapat koordinasi Notaris, MPW, MPD tanggal 10 September 2020 di Hotel Swiss Bell, telah mendapatkan putusan pemberhentian dari Menteri Hukum dan HAM dan akan segera disampaikan kepada yang bersangkutan di Kota Tual saat dilakukan kunjungan berkala.

Terdapat sejumlah kendala dalam penerapan sanksi, salah satu diantaranya belum diatur bagaimana sistem monitoring dan eksekusi putusan. Di samping itu, keterbatasan anggaran juga menyebabkan monitoring pelaksanaan putusan sulit dilakukan. Hal ini disebabkan oleh 3 (tiga) notaris yang diberi sanksi masing-masing berada di luar Kota Ambon, seperti di Kabupaten Aru, 
Kabupaten Buru, dan Kabupaten SBB yang secara geografis memerlukan anggaran yang besar untuk melakukan monitoring putusan di lokasi.

\section{E. Konsep Pengawasan Ideal MPWN Provinsi Maluku}

Kedudukan Majelis Pengawas Notaris baik yang berkedudukan secara Nasional seperti Majelis Pengawas Pusat, maupun di Provinsi dan Kabupaten/Kota adalah suatu badan yang mempunyai kewenangan dan kewajiban untuk melaksanakan pembinaan dan pengawasan terhadap Notaris berdasarkan UU No. 2 Tahun 2014. Perkataan "suatu badan" memiliki maksud bahwa sebagai suatu lembaga yang hakekatnya melaksanakan sebagian dari kewenangan Menteri Hukum dan Hak Asasi Manusia di bidang Kenotariatan, khususnya pembinaan dan pengawasan terhadap Notaris yang meliputi perilaku Notaris dan pelaksanaan jabatan Notaris.

Kedudukan yang demikian itu memposisikan Majelis Pengawas tata kerja, organisasi dan sistem pengawasannya terikat dan ditentukan oleh Menteri. Sebagai konsekuensi pembinaan dan pengawasan Notaris diberikan kepada Menteri berdasarkan UU No. 2 Tahun 2014, kemudian kewenangan itu didelegasikan kepada Majelis Pengawas secara berjenjang dari Pusat, Provinsi hingga ke Kabupaten/Kota.

Hakikat pengawasan yang tersurat dalam penjelasan UU No. 2 Tahun 2014 menegaskan bahwa ketentuan mengenai pengawasan terhadap pelaksanaan jabatan Notaris dilakukan dengan mengikutsertakan pihak ahli/akademisi, di samping Departemen yang tugas dan tanggung jawabnya di bidang Kenotariatan serta Organisasi Notaris. Ketentuan ini dimaksudkan untuk meningkatkan pelayanan dan perlindungan hukum yang lebih baik bagi masyarakat, sehingga konsep pengawasan sejatinya didesain untuk mewujudkan maksud dalam UU No. 2 Tahun 2014, yakni meningkatkan pelayanan dan perlindungan hukum yang lebih baik bagi masyarakat.

Guna merumuskan konsep atau model yang ideal terkait pengawasan MPWN Provinsi Maluku, maka digunakan pendekatan teori analisis sistem untuk mengurai kelemahan-kelemahan dari sisi substansi aturan sepanjang menyangkut kewenangan, sanksi, pelaksanaan pengawasan yang sudah diatur dan atau sedang berlaku (ius constitutum), baik dalam UU No. 2 Tahun 2014 maupun peraturanperaturan yang dikeluarkan oleh Kementerian Hukum dan HAM RI. Adapun pada aspek struktur hukum, harus menyorot soal efektivitas mekanisme pengawasan. Dilain sisi, badan pengawasan harus melakukan proses berjenjang, dimana mulai dari MPD, MPW hingga MPP. Dari aspek sarana dan prasaran lain, harus didukung oleh berbagai hal, seperti SDM, anggaran serta yang lebih penting budaya hukum, baik anggota MPWN maupun notaris itu sendiri.

Lebih lanjut, sebagai profesi hukum yang mulia (officium nobile), profesi jabatan Notaris menuntut adanya kecakapan dan keterampilan profesi yang tinggi yang harus dibalut dengan nilai-nilai moralitas. Hal ini bertujuan untuk menjaga harkat dan martabat profesi notaris guna menjamin kepastian, ketertiban dan perlindungan hukum masyarakat. 
Dalam praktiknya di Maluku, pemeriksaan protokol tidak dilakukan secara rutin setiap tahun, sebagaimana yang dikemukakan oleh Irvan Burangasi, bahwa: ${ }^{2}$

\begin{abstract}
"Pemeriksaan protokol menurut aturan memang dilakukan setiap tahun. Akan tetapi untuk kasus Notaris berinisial FG, pemeriksaan protokol hanya pernah dilakukan tahun 2017 saat pemantauan di Bula Kabupaten SBT. Hal ini disebabkan oleh keterbatasan anggaran di MPD. Adapun terkait pemeriksaan kepada yang bersangkutan, belum dilakukan melalui persidangan MPWN Provinsi Maluku. Akan tetapi, Ketua MPWN Provinsi Maluku telah menetapkan tim pemeriksa berdasarkan Nomor: M.04.MPWN Provinsi Maluku.07.20 Tahun 2020 tentang Pembentukan Majelis Pemeriksa Provinsi Maluku"
\end{abstract}

Berdasarkan hasil analisis data berkaitan dengan efektivitas pelaksanaan fungsi kewenangan pengawasan MPWN Provinsi Maluku dan berbagai data fakta hambatan yang dialami sebagaimana dalam pokok bahasan sebelumnya, maka ditawarkan suatu model atau desain konsep pengawasan MPWN dimana berupa Model Pencegahan dan Pengawasan Aktif. Model tersebut dapat dijalankan secara berkala maupun setiap waktu berdasarkan keperluan informasi terkait dugaan pelanggaran pelaksanaan jabatan Notaris dan pelanggaran perilaku Notaris.

Pengawasan aktif secara rutin juga bisa dikembangkan dengan sistem pengawasan dari segi hukum, yaitu suatu penilaian tentang keabsahan dari suatu akta yang telah dibuat notaris dimana berpotensi menimbulkan akibat hukum. Pengawasan ini dimungkinkan karena sesuai dengan kewenangan MPDN sebagaimana berdasarkan Pasal 70 UU No. 2 Tahun 2014. Tujuan yang ingin dicapai dengan menerapkan sistem pengawasan dari segi hukum adalah agar Notaris dalam melakukan tindakannya harus sesuai dengan norma-norma yang berlaku dalam rangka memberikan perlindungan hukum bagi masyarakat. Pemeriksaan rutin atau pemeriksaan administratif dan prilaku di MPD, MPW dan MPP merupakan langkah pencegahan dan pembinaan terhadap notaris dalam memberikan pelayanan yang maksimal kepada masyarakat.

Konsep ini juga sesuai dengan perkembangan sistem pengawasan yang telah dipraktikkan secara rule model dan dikenal 2 (dua) model penanganan dalam sistem pengawasan kepemiluan sebagaimana berdasarkan Pasal 454 ayat (1) Undang-Undang Republik Indonesia Nomor 7 Tahun 2017 tentang Pemilihan Umum, mengatur bahwa "pelanggaran Pemilu berasal dari temuan pelanggaran Pemilu dan laporan pelanggaran Pemilu".

\title{
KESIMPULAN
}

Berdasarkan uraian hasil dan pembahasan, maka dapat disimpulkan bahwa optimalisasi kewenangan MPWN Provinsi Maluku Tahun 2017-2020 telah berjalan sebagaimana berdasarkan Pasal 73 UU No. 2 Tahun 2014. Akan tetapi, terdapat beberapa faktor kendala dari sisi efektivitas fungsi kewenangan, khususnya faktor regulasi dan faktor penerapan sanksi. Dengan dasar kesimpulan tersebut, disarankan agar dilakukan revisi pada Pasal 73 UU No. 2 Tahun 2014, yaitu dengan memperkuat atau memperluas kewenangan MPW melalui model Pencegahan dan Pengawasan

2Wawancara dengan Sekretaris Majelis Pengawas wilayah Notaris Provinsi Maluku, Irvan Burangasi, pada Bulan Juli dan September 2020. 
Aktif, dimana dijalankan secara berkala maupun setiap waktu berdasarkan keperluan informasi terkait dugaan pelanggaran pelaksanaan jabatan Notaris dan pelanggaran perilaku Notaris.

\section{REFERENSI}

Abdul Bari Azed. (2008). Kebijakan Pemerintah di Bidang Kenotariatan (Edisi 8). Jakarta: Media Notariat.

Abdul Latif. (2014). Hukum Administrasi: Dalam Praktik Tindak Pidana Korupsi. Jakarta: Kencana Prenada Media Group.

Aminuddin Ilmar. (2018). Hukum Tata Pemerintahan. Jakarta: Kencana Prenada Media Group.

Aris Yulia. (2019). Profesi Notaris di Era Industrialisasi dalam Perspektif Transendensi Pancasila. Law and Justice, Universitas Muhammadiyah Surakarta, 4(1), hlm. 5667. doi: https://doi.org/10.23917/laj.v4i1.8045

Dendy Sugiono (Ed.) (2008). Kamus Besar Bahasa Indonesia: Pusat Bahasa. Jakarta: Departemen Pendidikan Nasional bekerjasama dengan PT. Gramedia Pustaka Utama.

Diana Halim Koentjoro. (2004). Hukum Administrasi Negara. Bogor: Ghalia Indonesia.

Endang Purwaningsih. (2015). Bentuk Pelanggaran Hukum Notaris di Wilayah Provinsi Banten dan Penegakan Hukumnya. Mimbar Hukum, Universitas Gadjah Mada, 27(1), hlm. 14-28. doi: https://doi.org/10.22146/jmh.15907

Erna Ristiani. (2010). "Peranan dan Fungsi Majelis Pengawas Wilayah terhadap Pelaksanaan Tugas Jabatan Notaris". Tesis. Program Studi Magister Kenotariatan, Program Pascasarjana Universitas Diponegoro, Semarang.

Eureika Kezia Sakudu \& Wahyuni Safitri. (2017). Peranan Majelis Pengawas Wilayah Notaris dalam Melakukan Pengawasan terhadap Pelaksanaan Jabatan Notaris terkait Undang-Undang Nomor 2 Tahun 2014 tentang Jabatan Notaris. Yuriska: Jurnal Ilmiah Hukum, Universitas Widya Gama Mahakam Samarinda, 9(2), hlm. 65-74. doi: https://doi.org/10.24903/yrs.v9i2.222

F. A. M. Stroink \& J. G. Steenbeek. (1985). Inleiding in het Staats-en Administratief Recht. Alphen aan den Rijn: Samson H.D. Tjeenk Willink.

H. D. van Wijk. (1976). Hoofdstukken Van Administratief Recht. Gravenhage: VUGA Uitgeverij.

Hans Kelsen. (1992). Introduction to the Problems of Legal Theory (Terj. oleh Bonnie Litschewski Paulson \& Stanley L. Paulson). Oxford: Clarendon Press.

Henny Saida Flora. (2012). Tanggung Jawab Notaris Pengganti dalam Pembuatan Akta. Kanun: Jurnal Ilmu Hukum, Universitas Syiah Kuala, 14(2), hlm. 179-199.

Jeffry Tanugraha. (2013). Akibat Hukum bagi Notaris yang Rangkap Jabatan sebagai Pejabat Negara. Hukum Bisnis dan Administrasi Negara, Universitas Dr. Soetomo, 14(2), hlm. 1-25. doi: https://dx.doi.org/10.25139/mih.v1i2.735 
Keputusan Menteri Kehakiman dan Hak Asasi Manusia Republik Indonesia Nomor M-01.HT.03.01 Tahun 2003 tentang Kenotarisan.

Kongres Luar Biasa Ikatan Notaris Indonesia Tahun 2015 tentang Perubahan Kode Etik Notaris.

Nasaruddin Umar \& Fahri Bachmid. (2020). Efektivitas Program Pembinaan Kesadaran Berbangsa dan Bernegara terhadap Narapidana Khusus Korupsi di Lembaga Pemasyarakatan Kelas IIA Ambon. Sovereign: Jurnal Ilmiah Hukum, CV. Social Politic Genius (SIGn), 2(2), hlm. 52-69. doi: https://doi.org/10.37276/sjih. v2i2.38

Neky Kuntjoro. (2016). Efektivitas Pengawasan Majelis Pengawas Daerah (MPD) Kota Yogyakarta terhadap Perilaku Notaris di Kota Yogyakarta menurut Kode Etik Notaris. Lex Renaissance, Universitas Islam Indonesia, 1(2), hlm. 201-205. doi: https://doi.org/10.20885/JLR.vol1.iss2.art5

Olivia Yanuari Huslan. (2019). Pelaksanaan Jabatan dan Pengawasan bagi Notaris yang Meninggalkan Wilayah Jabatan (Studi Kasus Notaris X Berkedudukan di Bali, Meninggalkan Wilayah Jabatan ke Kota Makassar). Indonesian Notary, Universitas Indonesia, 1(2), hlm. 1-26.

Peraturan Menteri Hukum dan Hak Asasi Manusia Republik Indonesia Nomor 40 Tahun 2015 tentang Susunan Organisasi, Tata Cara Pengangkatan Anggota, Pemberhentian Anggota, dan Tata Kerja Majelis Pengawas. (Berita Negara Republik Indonesia Tahun 2015 Nomor 1787).

Peraturan Menteri Hukum dan Hak Asasi Manusia Republik Indonesia Nomor 61 Tahun 2016 tentang Tata Cara Penjatuhan Sanksi Administratif terhadap Notaris. (Berita Negara Republik Indonesia Tahun 2016 Nomor 2128).

Philipus M. Hadjon, et al. (Eds.). (2011). Hukum Administrasi dan Tindak Pidana Korupsi. Yogyakarta: UGM Press.

Said Sampara \& La Ode Husen. (2016). Metode Penelitian Hukum. Makassar: Kretakupa Print.

Sri Yuniati. (2017). Mekanisme Pemberian Sanksi terhadap Notaris yang Melakukan Pelanggaran Kode Etik Jabatan Notaris. Jurnal Akta, Universitas Islam Sultan Agung Semarang, 4(4), hlm. 585-590.

Tatiek Sri Djatmiati. (2004). "Prinsip Izin Usaha Industri di Indonesia”. Disertasi. Program Pascasarjana, Universitas Airlangga, Surabaya.

Undang-Undang Republik Indonesia Nomor 30 Tahun 2004 tentang Jabatan Notaris. (Lembaran Negara Republik Indonesia Tahun 2004 Nomor 117. Tambahan Lembaran Negara Republik Indonesia Nomor 4432).

Undang-Undang Republik Indonesia Nomor 2 Tahun 2014 tentang Perubahan atas Undang-Undang Nomor 30 Tahun 2004 tentang Jabatan Notaris. (Lembaran Negara Republik Indonesia Tahun 2014 Nomor 3. Tambahan Lembaran Negara Republik Indonesia Nomor 5491). 
Undang-Undang Republik Indonesia Nomor 30 Tahun 2014 tentang Administrasi Pemerintahan. (Lembaran Negara Republik Indonesia Tahun 2014 Nomor 292. Tambahan Lembaran Negara Republik Indonesia Nomor 5601).

Undang-Undang Republik Indonesia Nomor 7 Tahun 2017 tentang Pemilihan Umum. (Lembaran Negara Republik Indonesia Tahun 2017 Nomor 182. Tambahan Lembaran Negara Republik Indonesia Nomor 6109).

I Nasaruddin Umar \& Fahri Bachmid. (2020). Optimalisasi Kewenangan Majelis I I Pengawas Wilayah Notaris Provinsi Maluku. Sovereign: Jurnal Ilmiah Hukum, CV. Social ! I Politic Genius (SIGn), 2(3), hlm. 1-14. doi: https://doi.org/10.37276/sjih.v2i3.37

ᄂ _ _ _ _ _ _ _ _ _ _ _ _ _ _ _ _ _ _ _ _ _ _ _ _ _ _ _ _ _ _ . . 